\title{
WŁOSKI MISJONARZ-LEKSYKOGRAF W DZIEWIĘTNASTOWIECZNEJ BUŁGARII
}

\author{
MARIOLA WALCZAK-MiKOŁAJCZAKOWA \\ Adam Mickiewicz University in Poznan
}

\begin{abstract}
AN ITALIAN MISSIONARY-LEXICOGRAPHER IN THE NINETEENTH-CENTURY BUL-
GARIA. The article discusses Magalena Abadzhieva's book The Bulgarian-Italian Handwritten Dictionary of Father Maurizio of 1845 : Study and Text. Sofia: BAS, 2020 [Абаджиева, Магдалена. Ръкописният българо-италиански речник на отец Маурицио от 1845 г. : Изследване и текст. София: БАН, 2020] in the context of the history of Bulgarian Catholics and their writings. It reveals several disputable points concerning the interpretation of separate words appearing in the Italian missionary's dictionary, such as arkangel, doniza, kugè. The author confirms the thesis that the work of Father Maurizio may be included in the canon of Bulgarian Catholic literature, as it is a valuable source of knowledge about the Paulician dialect.
\end{abstract}

Keywords: Bulgarian Catholics, Italian lexicographer, dictionary, Paulician dialect

Przed kilkoma miesiącami nakładem Wydawnictwa Bułgarskiej Akademii Nauk ukazał się (wraz z komentarzem) bułgarsko-włoski słownik spisany przez ojca Maurizia z zakonu kapucynów, katolickiego misjonarza, który przebywał w Bułgarii przez 12 lat, od roku 1844 do 1856. O literackiej działalności o. Maurizia z Castellazzo wspominał już Lubomir Mileticz w swoim znanym eseju Нашите павликяни (Miletich 1903), który do dziś pozostaje podstawowym źródłem wiedzy na temat Bułgarów-katolików. W notatkach nestora bułgarskiego językoznawstwa nie było jednak mowy o słowniku, lecz o ośmiu rękopiśmiennych zeszytach, zawierających 23 skrupulatnie datowane niedzielne i świąteczne homilie. Ironia losu sprawiła, że opisane przez prof. Mileticza zeszyty do dziś nie zostały odnalezione, natomiast w Oddziale Rękopisów Narodowego Muzeum Historycznego w Sofii gdzie przechowywane są mało znane materiały (rękopisy i starodruki) dotyczące mniejszości katolickiej w Bułgarii, Magdalena Abadżiewa znalazła liczący 104 karty rękopis słownika bułgarsko-włoskiego z 1845 roku. Słownik ten, zawierający około 3500 wyrazów, został przez Abadżiewą zidentyfikowany jako spisany ręką ojca Maurizia, a następnie opracowany, omówiony i opublikowany dokładnie 175 lat po jego napisaniu. 
Magdalena Abadżiewa od lat zajmuje się piśmiennictwem Bułgarów-katolików. W roku 2017 obroniła dysertację na temat Павликянската книжнина от XVIII век в историята на българския език, w której szczegółowo omówiła znaczenie twórczości tzw. paulicjan $^{1}$ dla rozwoju nowobułgarskiego języka literackiego, a także scharakteryzowała gramatykę i morfologię dialektu paulicjańskiego, który stanowił tworzywo działalności piśmienniczej katolików. Wydanie i omówienie słownika ojca Maurizia z Castellazzo jest rezultatem badań Abadżiewej, prowadzonych w ramach projektu Книжнината на българите католици и границата между Източните и Западните Балкани XVII-XIX век. Częściowe rezultaty badań nad słownikiem autorka omówiła już wcześniej, w artykule napisanym wspólnie z Marianą Cibranską-Kostową (Abadzhieva \& Tsibranska-Kostova 2019).

Przystępując do pracy nad słownikiem włoskiego misjonarza, Abadżiewa musiała zadać sobie ważne pytanie: czy dzieło spisane przez cudzoziemca, służące wszakże pracy wśród Bułgarów, można zaliczyć do dorobku piśmiennictwa bułgarskiego?² Odpowiada na niew sposób twierdzący w rozdziale II swojego opracowania, przytaczając niepodważalne argumenty:

\begin{abstract}
Като се изяснява обсегът на понятието книжнина на българите католиции не може единственият критерий за включване в него да бъде националната и конфесионална приналдежност на авторите на произведенията, но също така трябва да се види и предназначението на текстовете. Този дял от българската литература се представя най-вече от образци, целенасочено създадени за тази част от българското население. Не изключвам вероятността речникът на отец Маурицио да е бил използван и от българите католици с цел изучаването на италиански език - практика, която днес е силно застъпена в католическите села около Пловдив. (Abadzhieva 2020: 12)
\end{abstract}

Wypada zgodzić się z takim tokiem rozumowania, tym bardziej, że słownik ojca Maurizia stanowi cenne źródło informacji nie tylko o zasobach leksykalnych dialektu paulicjańskiego, ale także o jego fonetyce i fonologii. Włoski misjonarz zapisywał wszak to, co słyszał od swoich bułgarskich współwyznawców i starał się precyzyjnie określić znaczenie poszczególnych słów.

Z materiałów przechowywanych w parafialnych archiwach wynika, że misjonarz przybył do Bułgarii w roku 1844 i przez pierwsze cztery lata pracował wśród katolików we wsi Duwanli, a następnie został przeniesiony do Chambarli (dziś Żitnica), a jego praca przebiegała - jak napisali w liście do autorki włoscy kapucyni z archiwum zakonnego

1 Na temat dyskusji wokół nazwy mniejszości katolickiej w Bułgarii zob. Walczak-Mikolajczakowa 2004: 11-27.

2 Podobny problem nurtował też Krasimira Stanczewa, który wszakże innego z włoskich misjonarzy, ojca Eduardo z Turynu, określił mianem водещ павликянски книжовник (Stantchev 1995: 170). 
w Piemoncie - tra le avversità del governo turco (Abadzhieva 2020: 13). Obie wsie, w których pracował ojciec Maurizio położone są niedaleko Płowdiwu i wymieniono je już w księdze chrztów prowadzonej w Płowdiwie od 1729 roku. Ksiądz Michaił Dobromirow wspominał tam, że u podnóża Rodopów istniały na początku XVIII wieku następujące miejscowości należące do diecezji płowdiwskiej: Płowdiw z siedzibą biskupa oraz wsie Kałyczi, Parczewicz, Boliarino, Sekirowo, Czałykowo, Duwanli, Dawudżewo i Chambarli (Walczak-Mikolajczakowa 2004: 24). Część z tych wsi nosi dzisiaj inne nazwy, a Kałyczi, Parczewicz i Sekirowo zostały połączone w jeden organizm miejski - Rakowski. Miasto Rakowski, podobnie zresztą jak Żitnica, w której pracował ojciec Maurizio (w jego czasach znana pod nazwą Chambarli) do dziś pozostają znaczącymi ośrodkami katolickimi. W połowie XIX wieku obie znalazły się w jurysdykcji nowo powołanego sofijsko-płowdiwskiego wikariatu apostolskiego z siedzibą w Płowdiwie, którym przez dwadzieścia lat kierował ojciec Andrea Canova, także z włoskiego zakonu kapucynów. Z jego raportu wynika, że okręg płowdiwski w 1848 r. zamieszkiwało prawie 6ooo katolików. Dla nich i dla ich mniej licznych współwyznawców z północy kraju już od II połowy XVIII wieku rodzimi autorzy tworzyli dzieła w dialekcie paulicjańskim, zapisywane za pomocą alfabetu łacińskiego.

Cześć utworów z literatury paulicjańskiej została przez L. Mileticza przetranskrybowana na cyrylicę, większość jednak opublikowano w oryginalnym zapisie łacinką. Ich prawidłowe odczytanie zawsze nastręczało szeregu problemów, gdyż najbardziej płodni autorzy z kręgu katolickiego - tworzący pod koniec XVIII wieku Petyr Kowaczew Carski i Paweł Duwanlija - wypracowywali dopiero zasady ortograficzne dla zapisu rodzimej mowy, w ich twórczości zdarzają się wahania co do zapisu i widoczny jest brak pełnej konsekwencji. Dość szybko przyjął się zapis na sposób włoski, a mimo to do dziś pozostały nierozstrzygnięte niektóre kwestie dotyczące poprawnego odczytywania wyrazów (tzn. wymowy poszczególnych głosek), np. czy nagłosowe cia- jest tożsame z bułgarskim чa- (jak w transkrypcji Mileticza, por. ciarqua - чарква, ciado - чадо), czy raczej wymowa tej grupy była bardzo miękka, zbliżona do чя-. Dlatego słownik bułgarsko-włoski ojca Maurizio okazuje się dziełem przydatnym również dla dialektologów, gdyż zapis ze słuchu dokonany ręką obcokrajowca, stosującego tę samą grafię i ortografię, co twórcy z kręgu paulicjańskiego jest źródłem trudnym do przecenienia - nieobarczony wiedzą na temat etymologii wyrazów, ojciec Maurizio zapisywał to, co słyszał i tak, jak słyszał, bez odwoływania się do historii czy budowy morfologicznej danego słowa. Jego słownik jest więc bezcennym źródłem informacji z zakresu fonetyki i fonologii.

Osobliwościom ortografii słownika bułgarsko-włoskiego Magdalena Abadżiewa poświęciła obszerny rozdział VI (s. 33-46), zaś fonetyce rozdział VII (s. 47-58). Są to opisy szczegółowe i rzetelne. Szkoda więc, że podczas omawiania zapisu rzeczownika arkangel, 
w toku swojego wywodu autorka wprowadziła współczesny alfabet cyrylicki, co zakłóciło klarowność jej wypowiedzi. Czytamy tam:

Италианско влияние може да се търси и във фонетичния облик на определени думи, както е в случая с архангел. Тя е предадена в речника с $\kappa$ (arkangel), както е в италиански (arcangelo), а не с $x$. (Abadzieva 2020: 38 )

O ile użycie litery к nie zakłóca zrozumienia wywodu (ze względu na podobieństwo w obu alfabetach), o tyle litera $x$ może powodować pewne nieporozumienia - wszak dwie strony wcześniej autorka objaśnia, że w taki właśnie sposób (tzn. za pomocą litery $x$ ) zapisywano

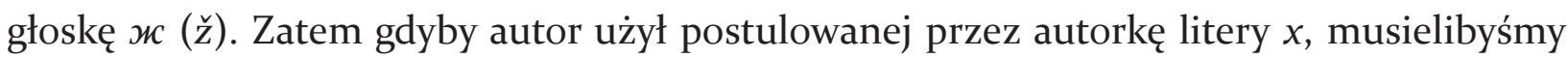
wyraz zapisany w postaci *arxangel odczytać jako aržangel. Intencje Abadżiewej są w pełni zrozumiałe, jednak balansowanie między opisem głosek i liter pochodzących z dwóch alfabetów wymaga wielkiej ostrożności - tym większej, jeśli mamy do czynienia z sytuacją, w której tożsame litery w dwu różnych alfabetach oznaczają dwie różne głoski, a w akapicie poprzedzającym cytowane zdanie wymienia się szereg przykładów, w których litera x oznacza właśnie $\varkappa_{(\check{z})}$ (alfabetycznie, od blaxen, boxanstuo po xaltàk, xelezo).

Nie mogę się też zgodzić ze sformułowaniami typu на място на малката носовка стои последователно графемата е: messo, pedisèt, pet и др. (Abadzhieva 2020: 48), gdyż tak wyrażona opinia sugeruje, że ojciec Maurizio zapisywał e w miejscu nosówki, czyli tam, gdzie słyszał dźwięk ę (на място на малката носовка). Tymczasem w rzeczywistości paulicjanie już od wieków nie wymawiali nosówek, a misjonarz, który nie znał etymologii wyrazów i nie był biegły w języku staro-cerkiewno-słowiańskim, zapisywał po prostu to, co słyszał, w sposób możliwie najlepiej oddający wymowę, czyli w tym wypadku dźwięk e. Czynił to - jak sądzę - bez świadomości, że owo e znajduje się w miejscu małej nosówki.

Najwięcej wątpliwości budzi odczytanie słowa kugè (Abadzieva 2020: 48; w słowniku na s. 26) jako къде (scs. кжАє), tym bardziej, że we włoskim objaśnieniu wyrazu czytamy Molto tempo fa ('dawno temu'). Wyraz ten został wprawdzie w słowniku dopisany po jakimś czasie, ale charakter pisma wskazuje, że autorem dopisku jest sam ojciec Maurizio, który nigdy nie mylił alfabetu łacińskiego z cyrylickim - nic zatem nie wyjaśnia, dlaczego głoska $d$ miałaby być zapisana za pomocą litery $g$. Wydaje się, że dopisek ten został wykonany mało starannie $\mathrm{z}$ trudną do odczytania ostatnią literą ${ }^{1}$, i że w istocie mamy do czynienia z wyrazem kogà zapisanym zgodnie ze zredukowaną wymową o > u i zaznaczonym miejscem akcentu. Takie odczytanie (kuga) wydaje się bliższe włoskiej definicji wyrazu.

1 Pracując z paulicjańskimi rękopisami z końca XVIII i początku XIX wieku wielokrotnie miałam wątpliwości co do prawidłowego odczytywania liter $e$ i $a$. 
Ostatnia uwaga dotyczy wyrazu doniza (tłumaczonego na język włoski jako brocca), co do którego autorka - nie znajdując go w źródłach leksykograficznych - wysuwa przypuszczenie, że pochodzi od słowa дъно ('dno'). Wydaje się, że chodzi tu o leksem tożsamy $\mathrm{z}$ polskim donica, a w takim razie wyprowadzanie jego znaczenia od rzeczownika uznać należy za nietrafne. W Stowniku etymologicznym języka polskiego znaczenie i etymologię donicy Wiesław Boryś objaśnia następująco:

Od XV w. (daw. od XVI w. i dial. też dunica, dial. dónica), 'głęboka gliniana misa, dzieża, makutra', 'naczynie do hodowania roślin ozdobnych', daw. i dial. 'naczynie do dojenia, skopek'. (...) Psł. *dojьnica 'naczynie (drewniane), do którego się doi mleko, skopek', od przym. *dojьnъ 'odnoszący się do dojenia, związany z dojeniem' (...). (Borys 2008: 118-119)

Wymienione wyżej drobne wątpliwości nie zmieniają faktu, że opublikowanie słownika bułgarsko-włoskiego autorstwa ojca Maurizia z Castellazzo, misjonarza niezwykle zaangażowanego w pracę na rzecz swoich parafian, jest ważnym wydarzeniem naukowym. Docenić trud bułgarskiej badaczki powinny nie tylko osoby zajmujące się mniejszością katolicką w Bułgarii, ale wszyscy dialektolodzy i historycy języka bułgarskiego.

W moim przekonaniu publikacja tego słownika otwiera drogę do dalszych badań nie tylko nad językiem, ale także nad życiem codziennym bułgarskich katolików w połowie XIX wieku. Jedną z możliwych ścieżek badawczych otwiera Magdalenie Abadżiewej otrzymanie od włoskich franciszkanów recept spisanych ręką ojca Maurizia. Autorka wspomina, że świadczą one o zainteresowaniu misjonarza kwestią chorób i ich leczenia. Jeśli weźmiemy pod uwagę, że w słowniku obszerną grupę leksemów tworzą nazwy części ludzkiego ciała, nazwy roślin (często ziół leczniczych), a także nazwy chorób, to możemy wyrazić przekonanie, że autorka omawianego opracowania, będąc w posiadaniu wspomnianych recept zechce się pokusić o przedstawienie problematyki związanej z chorobami wśród paulicjan i sposobami ich leczenia. Może wśród nieprzebadanych materiałów archiwalnych Muzeum Historycznego w Sofii znajdą się jeszcze inne źródła związane z tą tematyką? Z wielką przyjemnością sięgnę do takiego artykułu. 


\section{REFERENCES}

Abadzhieva 2020: Abadzhieva, Magdalena. The Bulgarian-Italian Handwritten Dictionary of Father Maurizio of 1845. Sofia: Bulgarian Academy of Science, 2020. [In Bulgarian: Абаджиева, Магдалена. Ръкописният българо-италиански речник на отец Маурицио от 18452. Изследване и текст. София: Институт за българския език „Проф. Любомир Андрейчин”, БАН, 2020.]

Abadzhieva \& Tsibranska-Kostova 2019: Abadzhieva, Magdalena \& Tsibranska-Kostova, Mariana. "The Bulgarian-Italian Handwritten Dictionary of Father Maurizio of 1845." Foreign Language Teaching, vol. 46, book 5 (2019): 498-507. [In Bulgarian: Абаджиева, Магдалена \& ЦибранскаКостова, Марияна. „Ръкописният българо-италиански речник на отец Маурицио от 1845 г.“ Чуждоезиково обучение, т. 46, кн. 5 (2019): 498-507.]

Borys 20o8: Borys, Wieslaw. Ethymological Dictionary of the Polish Language. Krakow: Wydawnictwo Literackie, 2008. [In Polish: Boryś, Wiesław. Stownik etymologiczny języka polskiego. Kraków: Wydawnictwo Literackie, 2008.]

Miletich 1903: Miletich, Lyubomir. "Our Paulicians." The Folklore and Ethnography Collection (SbNUNK), book 19 (1903): 1-369. [In Bulgarian: Милетич. Любомир. „Нашите павликяни.“ СбНУНК, кн. 19 (1903): 1-369.]

Stantchev 1995: Stantchev, Krassimir. "Father Eduardo from Turin and the Bulgarian Paulician literature." In Papers from the Fifth Bulgarian-Italian Symposium, Pisa 24-28 Sept. 1990: 169-181. Rome: La Fenice, 1995. [In Bulgarian: Станчев, Красимир. „Отец Едуардо от Торино и българската павликянска книжнина." В: Доклади от Петия Българо-италиански симпозиум. Пиза 24-28 септ. 1990 / Atti del Quinto Convegno Italo-Bulgaro: 169-181. Roma: La Fenice, 1995.] Walczak-Mikolajczakowa 2004: Walczak-Mikolajczakowa, Mariola. Catholic Writings in Bulgaria. The Language of Literary Works of the Second Half of the 18th Century. Poznan: Adam Mickiewicz University Press, 2004. [In Polish: Walczak-Mikołajczakowa, Mariola. Piśmiennictwo katolickie w Bułgarii. Język utworów II połowy XVIII wieku. Poznań: Wydawnictwo Naukowe UAM, 2004.] 